\title{
Effective Risk Management In Organizations:The Nigerian Experience
}

\author{
Ndubuisi-Okolo Purity Uzoamaka \\ Department Of Business Administration \\ Nnamdi Azikiwe University,Awka,Nigeria \\ E-mail:purend2@yahoo. Com \\ And \\ Okonkwo Rita Ifeoma \\ Department Of Business Administration \\ Nnamdi Azikiwe University,Awka \\ And \\ Ifeoma Amakor \\ Department Of Banking And Finance \\ Nnamdi Azikiwe University,Awka \\ Tel:08036222388
}

\begin{abstract}
This study is an investigation on effective risk management with respect to organizations in Nigeria. The objective of the paper is to examine factors militating against effective risk management in organizations. The paper adopted content analysis of library materials, journal publications, internet materials and other documented materials relevant to the subject matter. It was concluded that effective risk management is a proactive approach towards mitigating the impact of threats, maximizing opportunities and optimizing the achievement of objectives. It was recommended that managers of organizations in Nigeria should imbibe and articulate good corporate risk attitude, strong risk culture and clearer risk appetite.
\end{abstract}

Key words: Risk, Risk management, effective risk management, risk culture, risk attitude, risk appetite and organizations.

\section{Council for Innovative Research}

Peer Review Research Publishing System

\section{Journal: INTERNATIONAL JOURNAL OF COMPUTERS \& TECHNOLOGY}

Vol 10, No.8

\section{editor@cirworld.com}

www.cirworld.com, member.cirworld.com 


\section{INTRODUCTION}

Cultural theorists such as Mary Douglas Aaron Wildavsky and John Adams have shown that risk means different things in different settings and organizations(Douglas and Wildavsky 1983;Adams 1995).Risk has no universal definition; hence variability of outcomes is a common way of expressing risk(Skipper 1997).Risk has two parts: uncertainty and consequence. Consequently, risk can be described in terms of its effects (positive or negative) on objective. Uncertainty and risk present in Nigerian organizations have not been effectively managed (Damodaran 2008;Kannan and Thangravel 2008).Risk can be categorized into :systematic and unsystematic risk. Systematic risk refers to the risk inherent in the entire system or entire market. It is sometimes called market risk, systematic risk or undiversified risk. This is a type of risk that cannot be avoided through diversification whereas unsystematic risk is risk associated with individual assets and hence can be avoided through diversification. It is also known as specific risk, residual and diversification risk. The type and degree of risks an organization may be exposured to depend upon a number of factors, such as its size, complexity of business activities, volume (SBP 2003,P.1).Risk is a concept which affects individuals, groups and organization as a whole. Risk is very incidental to life. It permeates economic activities because risk is a life wire of every organization (Shimpi 2001).

Moreover, risk sometimes, entails some economic benefits as organizations may derive gains by taking risks. Business grows through risk taking(Drucker 1997,Kannan and Thangravel 2008). Risk is integral to opportunities and threats which adversely affect an action or expected outcome(Keys 2009,Lowe2010). Therefore, getting rid of risk undermines the source of value Creation thereby truncates potential opportunities(Knight and petty 2001;Grazino and A,ggraval 2005;Garavan 2007).In essence, to Organizations risks are uncertainty that matters(Hilson and Murray-Webster 2011). Risk management requires the acknowledgement that risk is a reality and the commitment to identify and manage risk(Galorath 2006).It is a process that should seek to reduce and control risks, enhance benefits and avoid detriments from speculative exposures. The objective of risk management is to maximize the potential for success and minimize the probability of future losses(Anderson and Terp 2006).Risk that become problematic can negatively affect cost,time,quality system performance.

Risk management involves identifying; measuring, monitoring and controlling risks. The process is to ensure that the individual clearly understands risk management and fulfills the business strategy and objectives. Risk management is an invaluable tool for managing uncertainty associated with business organizations that have always practice some forms of risk management implicitly and explicitly (Meulbroek 2002). It is not a new concept because risk management techniques such as risk reduction, through safety, quality control and hazard education etc have been in existence for a long time (Doherty 2000). Meanwhile, risk management is not a process of avoiding risks. It does not eliminate risks but manages risks associated with operations in organizations thereby maximizing opportunities and minimizing threats.

Therefore, effective risk management is so important that it can increase project success of risk management. The main process include content analysis, risk identification, risk analysis, risk evaluation, risk treatment, monitoring and review; communication and consulting. The degree of effective risk management actions varies among business organizations which is subject to risk culture and risk appetite(Hilson and Murray-webster 2011). The success of any organization depends upon effective risk management(Jorion 2001,2009).Effective risk management align with organizational assumptions and greatly help in overcoming the possibilities of the business failure(Gupta,2011).

Moreover, effective risk management reduces earning volatility, maximize value for shareholders and promotes job security and financial security in the organization(Lam 2007).It is also a proactive approach to minimize threats, maximize opportunities and optimize achievement of objectives(Pearce and Robinson 2000;Hilson and Murray Webster 2004,Gray and Larson 2006;Rejda 2011).

Finally, managing a business successfully involves reducing risk and taking advantage of good ones. Organizational threats cannot be completely eliminated; hence the best managed business may still experience losses due to unaccounted threats (Kimball 2000; Stulz 2008; Hubbard 2009; Jorion 2009).

\section{Objective Of The Study}

1. To examine factors militating against effective risk management in organizations

\section{Conceptual and Empirical Review:}

Stulz(1996)argues that risk management create value by reducing or eliminating the costs and losses of financial distress. Root and scharfstein and Stein (1993) advocates that risk management adds value if it helps the organization avoid unfavorable outcomes or states of the world that permit it. This theory suggests that risk management is more valuable for highly leveraged organizations that also have volatile earnings and limited cash reserves. 'Desender and Laffuentes $2010 ; 2012$ ) in agreement with(Froot at el 1993) posits that it is obvious that effective risk management systems add value to organizations, Some organizations pointed out that voluntary adoption of effective risk management systems are evidence of their benefits.

The International Standard Organization 31000 risk management guidance treats risk as two-sided variablility advocating that effective risk management should not only reduce the impact of unfavourable events but help managers to identify upside opportunities. Others claim that effective risk management help organization improve their resource allocation, leading to better capital efficiency and greater return on equity. 
Norcea (2009) opined that experience has taught managers that a given risk model will work in some contexts not in others. Carey (2002) reviews the Turnball's approach for effective risk management. He describes the Turnball report and how to apply this approach in order to manage risk. The approaches include: The importance of sound judgment, identification issues, keeping content of your reputation, assessing the importance of risks, verifying your judgment, changing management, embedding risks, cultural changes and remuneration issues.

Ifinedo (2008) investigates the impact of contingency factors such as top management support, business vision and external expertise. The results show that top management support influences the success level of the organizational system .In the word of Zwikaell (2008), he argues that the high importance of top management support is considered to be among the critical success factors for project management.

Young and Jordan (2008) suggest that the essence of top management support related to effective decision making to manage risk and to authorize business process change. They opined that successful mitigation or bearing of risk is contingent upon support and commitment from top management. Hasanali(2002) states that commitment and support from top management plays a key role in influencing the success in almost any initiative within an organization. In the words of Henrikson and Uhlenteldt(2006),top management formulates and decides objectives and strategies for organizational risk management activities, mission and overall objectives. Carey(2001) reviewed the critical success factors to effective risk management which include: commitment and support from top management, communication, culture ,organization structure, information technology, training and trust.

Finniston(1975)said that the gathering, storage, delivery and communication of infrastructure in broadest sense is a growing concern. Quirke (1996) reveals that commitment is an appropriate channel to deliver messages. Grabowski and Roberts (1999) claim that communication is an important consideration for effective risk management and that it plays an important role in risk mitigation. The communication process provides opportunities for members to understand their roles and responsibilities as the structure of the organization changes.

Grabowski and Roberts (1999) suggest that risk management requires the combination of several cultures that make the system into a cohesive whole in which the deep assumptions espoused value of each of the member organizations can be built around the need for melding a culture of reliability. Stank, Daugherty and Gustio(1994) believe that organizational structure involves an organization's internal pattern of risks, authority and communication. Hunter (2002) supports the idea that organizational structure provides the authority to predetermine the way employees work.

NSW Department of State and Regional Development (2005) believe that setting clear objectives and guidelines are necessary for effective risk management. De Loach (2004)0 focuses on Enterprise-wide risk management to manage risks and to create and protect enterprise value. Treven (2003) maintains that the training methods used by organizations can be classified into two methods: On-job training which provides one-on-one instructions, coaching, job rotation and an apprenticeship/intership. The second method is off-the-job training which is conducted away from the worksite. It is said that success of an organization depends upon its staff or employees. It is important to ensure that an adequate supply of staff is equipped with the appropriate skills for special departmental or managerial positions. According to Fill and Mullins(1990),the purpose of training is to improve knowledge, skills and attitudes which in turn increase confidence, motivation and job satisfaction.NSW Department of State and Regional is in accord with Fill and Mullins propositions and suggest that effective risk management become a part of good business practice and include training staff appropriately. Information technology plays a key role in achieving an organization's objectives. Shin(1999) focuses on information technology to redesign business processes and to improve business profitability and productivity. Xenomorph (2007) argues that effective risk management is impossible without effective information technology. Hasanali (2002) says that large organizations will find it difficult to communicate and share information technology without information technology infrastructure .Rolland (2008) in his words suggests using information to derive effective risk management. It can create an important link between risk management and corporate performance. Tyler (2003) opined that trust is important to organization because of the strong desire to understand how to create effective corporation within organizations. Carey (2001) suggest that organizational structure must be reviewed regularly and adjusted to adapt to the changing or dynamic environments.

In view of all these, Oracle (2009) identifies four factors which have contributed immensely to the relative immaturity of risk management in most organizations in Nigeria. They include: lack of executive commitment to risk management, fragmented management activities, viewing risk management from traditional not predicative perspective, lack of alignment among corporate strategy and strategic alliances. Kimball 2002, Stulz 2008;Hubbard 2009;Jorion 2009)argue the authenticity of effective risk management in Nigerian context. They stated that in spite of all the risk management measures deployed in a number of organizations in Nigeria; organizations still suffer myriads of risks. Matei et et(2012) asserts that organizations fail due to unexpected losses generated by three categories of causes: insufficient capital, errors incurred in risk measurement and risk ignorance. Kamball (2000)in his own view posits that risk mitigation and management can fail for more subtle and indirect reasons which include: agency risk, shift or change in form of risk and incremental failure. Agency risk refers to the risk managers and employees create because of their inability to implement policies and procedures designed to mitigate and manage risk. Risk management incremental failure can be avoided through regular review of risk exposures and the management framework (Grabowski and Roberts 1997; Kimball 2000; Charette 2002;bozek and Tworek 2011).

Hubbard(2009) enumerated ten general causes of effective risk management failure .They are: confusion regarding the concept of risk, avoidable human errors in subjective judgment of risk, entirely ineffectual but popular subjective scoring, misconceptions that block the use of better existing methods, reoccurring errors, institutional factors due to unnecessary isolation of risk analysts from each other both within the organization and among others, unproductive 
incentive structures, some parts that have been measured do not work, some parts that do work are not used, except for certain quantitative methods in certain industries, the effectiveness of risk management is almost never managed.

In addition, (Kimball2000; Stulz 2008; Hubbard 2009; jorion 2009) classified risk management failure into two: operational failure and operator's failure. Operator's failure originates from an organization's managers errors and misconducts. Finally risk perception is responsible for the disagreement about the way of managing risk (Finucane et al 2000; Coyle 2002; Slovics and weber 2002).

\section{BENEFITS OF EFFECTIVE RISK MANAGEMENT}

According to Meulbroek (2002), Hilson (2006); Protivist (2006) the following benefits of effective risk management are espoused thus:

1. Saving resources, time, assets, income, property and personnel

11. Protection of an organization reputation and public image

111. Prevention and reduction of legal liabilities

Iv. Increasing stability of operations and promoting continuous improvement

v. Protecting people and environment from harm.

vi. Improving the ability to prepare for unforeseen unexpected situations.

\section{Theoretical Framework:}

Traditional risk management views risk as a source of single and unrelated elements where individual risk are categorized and managed separately while the wholistic or predicative approach visualizes risk $\mathrm{s}$ as opportunities as well as threats. For the purpose of this study, the investigators adopt the predicative approach to risk management which focuses on both threats and opportunities (wolf 2008, Hoyt and Liebbenberg 2011)

\section{CONCLUSION AND RECOMMENDATION}

Effective risk management is a proactive approach towards mitigating the impact of threats, maximizing opportunities, optimizing achievement of objectives .It does not eliminate risk completely but reduces its impact on organizations. Effective risk management should be approached from the predictive approach instead of adopting the long- aged traditional approach that views risk only as threats to individuals, groups and organizations. The study recommends that managers of various organizations in Nigeria should develop and incorporate good corporate risk culture, risk attitude and risk appetite. This is because risk attitude, strong risk culture and clearer risk appetite play significant role in determining an organizations' health and performance.

\section{REFERENCES.}

AL-Tamimi, H.and AL-Mazrooei,F.m(2007).Bank risk management:a comparison study of UAE national and foreign banks. The Journal of Risk Finance,vol 8(4),pp 394-409. Anderson,K and Terp,A.(2006), Risk Management Anderson T.J.(ed), Perspectives on strategic risk management. Denmark: Copenhagen Business School Press.

Buchler, K. Freeman Buchler, K. Freeman, A.and Hulme,R.(2008). The risk evolution. New York, NyrMckinsey and Company.

Carey, A(2001),"Effective risk management in financial institutions: Turnball approach" Balance Sheet,vol.9(3),pp 24-27.

Coskun(2012).Financial failure and risk management.Sermaye plyasaisi Dergisi,10(2) 100-109.

Coyle,B.(2002).Risk awareness and corporate governance. Kent: Financial World.

Deloach,j.(2004),"The new risk imperative-an enterprise -wide approach ,"Handbook of business strategy,pp29-34.

Doherty,N.A.(2000).Integrated risk management:Technologies and strategies for managing corporate risk.New York:Mc Graw-Hill.

Drucker, P.F.(1997).Management.An abridged and revised version of management:Tasks, responsibilities, practices.London:Pan Books Publishers.

Galorath,D.(2006),"Risk Management Success Factors,"PM World Today,vol 8(11),from http://www.pm forum.org

Garuba,A.O.(2000).Credit Risk Management in the Nigeria banking industry.Journal of Research in National 24
Development,8(2)Retrieved
2012,from:http://www.transcampus..org/JORIONDV8Dec2010//JournalsV8N02Dec201028.html.

December

Grabowski,M.and Roberts,K.(1997).Risk mitigation in large-scale systems. Lessons from high-reliability organizations .California Management Review, Summer 1999,152-159.

Gray,C.F and Larson,E.W(2006).Project Management: The managerial process(3 ${ }^{\text {rd }}$ ed.).New York,NY.Irwin/McGraw-Hill'.

Graziano,C.and Aggarwal,E.Wc. (2006). Suites gaining another member. Financial Executive,21(7),42-44. 
Gupta,P.K.(2004).Enterprise risk management sub -optimality to optimality Journal of Insurance and Risk Management 2(4).

Gupta,P.K(2011).Risk Management in Indian Companies: EWRM concerns and issues. The Journal of Risk Finance,12(2), 121-139.

Harris,S.(2006). How to implement an effective risk management Retrieved 26 April 2009,from http:// search reunity.techtarget.com/tip/1,289483, sid14 gci 1178859,00html.

Hasanali,F.(2002),"Critical Success factors of knowledge management" Retrieved 29 march 2009,from www.kmadvantage.com/docs/km.articles/Critical-Success-Factors-of-km.pdf

Henriksen,P.and Uhlenfeldt,T.(2006), Conteporary Enterprise-Wide Risk Management:107-130.Denmark:Copenhagen Business school Press.

Hilson,D.(2002).What is risk? Towards a common definition.Inform:Journal of the institute of risk management,11-12Retrieved 22 April 2012,from:http://www.risk-doctor.com/pdf files/def0402.pdf.

Hilson,D.(2006).Integrated risk management as a fromwork for organization success.Pin/Global Conference proceedings,Sealtle USA.Retrieved 22 April 2012,from, http://www. Risk-doctor.com/pdf files/ adv 13.pdf.

Hilson,D.A, and Murray-webster,R.9(2004).Understanding and managing risk attitude.Retrieved 23 April 2012 from:http://www. Kent.ac.uk/scar/events/final papers/Hillson \% 20\% 2B\%20 Murray-Webster.pdf.

Hilson ,D.A, and Murray-Webster,R.(2007).Using risk appetite and risk attitude ( $\left.2^{\text {nd }} \mathrm{ed}\right)$.Aldershort,uk:Gower.

Hilson,D,A, and Murray-Webster,R.(2011).Using risk appetite and risk attitude to support Appropriate risk taking:A new taxonomy and model Journal of Project Program and Portfolio management,2(1),29-46.

Hindson,A.(2011).Developing a risk culture.Risk Management Journal.12,12,28-29.

Hofstede,G.(2001),value and culture cultures consequences(ed).1-40.London:Saye Publications.

Hoyt,R.E.and Liebenberg,A.P.(2006).The value of enterprise risk management:Evidence from the U.S Insurance jndustry Retrieved 12 April 2012 from:http.://www..aria.org./meeting/200 6 papers/Hoytt Liebenberg ERM 070606pdf.

Hoyt,R.E.and Liebenberg,A.P(2011)The value of enterprise risk management. The Journal of risk insurance,78(4).

Hubbard,D.W.(2009). The failure of management:why its broken and how to fix it,Hoboker:New Jersey,John Wiley.

Jorion,P.(2001).Value at Risk. The new benchmark for managing financial risk.New York, NY:Mc:Graw-Hill.

Jorion,P.(2009).Risk management lessons from the credit crisis.European Financial Management,2009,1-20.Retrieved 23 April 2012 from:http://merage.uci:edu/Jorion/papers\%SCRisk Management Credit Crisis.Pdf.

Kaye,B.(2009):Risk management.London:The Chattered Insurance Institute.

Kelman,I.(2003).Defining risk.Flood Risk No:Newsletters 2,6-8.

Kimball,R,C(2000). Failures in risk management.New England Economic Review,January/February, 1-12.

Lam,J.(2001).Risk management. The CRO is here to stay.New York,NY:Prentice-Hall.

Liebenberg,A.P., and Hoyt,R.E(2003).The determinants of enterprise risk management.Evidence from the appointment of risk officers. Risk Management and Insurance Review,6,37-52.

Longman Dictionary of Contemporary English(2009), Retrieved 8 may 2009, from http://www. Idoceonline.com/dictionary.

Lowe,S.W(2010).Risk management.London:The Chartered Insurance Institute.

Matei,D,Cristea,D. and Capatina,A.(2012).Risk management in the age of turbulence-failures and challenges.Annuals of"Dunareade Jos"University of Galati Fascicle.Economics and applied informatics 2,17-22. Meulbroek,L.(2002).The promise and challenges of integrated risk management.Risk Management and Insurance Review,5(1),55-56.

Nist(2004),"Risk management Guide for Information Technology Systems."National Institute of Standards and Technology,Retrieved 29 march 2009,from http://csrc.nist.gov/publications/nistpubs/800-30/sp 800-30.pdf.

NSW Department of State and Regional Development(2005),"Risk management quide for small business.Global Risk Alliance on the instruction of the South Wales.Department of State and Regional Development,NSW Department of State and Regional Development.Retrieved 29 march 2009,from www.small business nsw.gov.au. Oracle(2009) .Risk Management:Protect and maximize stakeholder value.An oracle Governance,Risk and Compliance White Paper.Retrieved 23 April 2012 ,from:http:/www.Oracle.cm/111/solution/corporate governance/032434pdf.

Quirks,B.(1996),"Putting communication on management agenda"Harvard Business Review,vol 57(2),pp81-93

Rejda,P.A.(2011).Introduction to risk management and insurance $\left(11^{\text {th }}\right.$ ed).Upper Saddle River,NI:Pretice Hall 
Rolland,H.(2008),"Using it to derive effective risk management,"The Risk and Insurance Management Society,Inc.9RIMS), Retriv 30 March 30 2009,from www.rmmag.com

Shimpi,P.A(2001)Integrating corporate risk management.New York,NY:Trexere.

Slovics,P.and Weber,E.U.(2002).Perception of risk posed by extreme events:Risk management strategies in an uncertain world.Retrieved 12 March 2012,from:http;//www.ideo.columbia.edu//chrr/documents/meetinga/round table/white paper.

Stulz,R.M(2008).Risk management failures.What are they and when do they happen?Fisher College of Business.Working papers serial number no:wp2008-03-017.Ohio_:Ohio:Ohio unjversity.Retrieved 13 April 2012,from :http://papers.com/5013/papers.ssrn.com.cmf? abstract. $\overline{\mathrm{d}=127873}$

Tcankova,l.(2000),"Risk Identification;basic stage of risk management,Environmental management and Health.vol. 13(3,pp,290-297.

Treven,s(2003), International training:The training of managers for assignment abroad.,Educatiio+ Training,vol 45(8/9),pp555-557.

Tyler.T.R(2003),"Trust within organizations, “Personnel Review,vol.32(5),pp 555-568.

Wolf (2008) .The evolution of enterprise risk. The Actuary,5(3),19-20.

Yates,H.(2011).Insurance and banking. The butterfly effect. Risk management Professional,3,26-27. 